DOI: https://doi.org/10.32689/2523-4536/59-3

УДК 330.1:352

Данилюк Л. С. старший викладач кафедри управління персоналом та економіки праці, ПрАТ «ВНЗ «Міжрегіональна Академія управління персоналом»; аспірантка, ДУ «Інститут економіко-правових досліджень імені В. К. Мамутова Національної академії наук України» ORCID: https://orcid.org/0000-0002-1661-8003

Danyliuk Liudmyla
Assistant Professor at the Department of Personnel Management and Labor Economics, Private Joint-Stock Company «Higher education institution «Interregional Academy of Personnel Management»;

Postgraduate Student, State Organization «V. Mamutov Institute of Economic and Legal Research of the National Academy of Sciences of Ukraine»

\title{
РОЗВИТОК ЕКОНОМІЧНОГО ПОТЕНЦІАЛУ ОБ'ЄДНАНИХ ТЕРИТОРІАЛЬНИХ ГРОМАД УКРАЇНИ: ПРОБЛЕМИ ТА ШЛЯХИ ЇХ ВИРІШЕННЯ
}

\section{DEVELOPMENT OF THE ECONOMIC POTENTIAL OF THE UNITED TERRITORIAL COMMUNITIES OF UKRAINE: PROBLEMS AND WAYS TO SOLVE THEM}

\footnotetext{
У статті окреслене коло завдань деиентралізаиї шодо підвишення рівня фінансової спроможності громади. Зазначена необхідність участі територіальних громад в реформуванні вітчизняної системи місиевого самоврядування. Визначені головні причини проблем розвитку економічного потенціалу об' єднаних територіальних громад України: 1) корумпована цеентралізована вертикаль державної влади, нераціональне використання нею фінансових і природних ресурсів; 2) відсутність ефективного та практичного механізму місиевого самоврядування, як демократичного механізму місиевого управління; 2) зростання рівня недовіри громадян до державної влади; 3) фінансово-економічна неспроможність переважної більшості громад; 4) недостатній рівень компетентності переважної кількості органів місиевої влади та громадського активу; 5) непорозуміння між місиевими державними установами, відсутність їх відповідальності перед громадою тощчо. Запропоновані організачійно-економічні підходи для стимулювання підприємницької активності мешканців громади і активізації підприємницького середовища. Увага приділяється дослідженню професійного складу населення, визначенню джерел та розподілу доходів, ресурсів, наявних у ОТГ. Наведений перелік пріоритетних питань кандидатам до виконавчих органів та Рад ОТГ: 1) професійні якості $і$ здатність бути віч-на-віч з громадою, шзо означає приведення системи місиевого самоврядування у відповідність з Конституцією України та готовність вирішувати проблеми громади; 2) вміння організувати комунікацію: громада - органи влади, створення Центру громадських комунікацій; 3) налагодження ичивілізованих відносин з інвесторами та приватним бізнесом: громада - забудовники промисловиі - аграрії (будувати великі промислові, житлові, туристичні, розважальні, інфраструктурні об 'єкти - тільки з дозволу громади); 4) приведення структури місиевого управління до оптимального варіанту, в першу чергу оптимізачія комунальних підприємств; 5) сприяти розвитку сферам охорони здоров'я, освіти, дитячої та молодіжної творчості і спорту, культури, транспорту; б) створення економної політики в сфері ЖКГ, захист інтересів ОСН; 7) створення та здійснення економічного та сочіального плану розвитку ОТГ, який відповідає інтересам місиевої громади. За основу економічного та людського потениіалу ОТГ необхідно застосовувати два надважливих показника. Перший - індекс якості життя кожного представника територіальної громади (здоров'я та довголіття, доступність освіти і гідний рівень життя). Цей індекс допоможе втримати людей від міграиії в інші регіони або за кордон і навпаки залучити додатковий людський ресурс. Конкурентоспроможність регіонів - ие другий надважливий індекс, який визначає здатність регіонів створити привабливе середовище для розвитку бізнесу й інвестицій. 3 иією метою формується загальнонаціональний рейтинг з урахуванням показника про власні доходи на одного мешкания, рівня дотаційності бюджету, шо не повинен перевищувати $30 \%$ від суми місиевих доходів та капітальних видатків на одного мешкания без субвенцій з держбюджету та питомої ваги видатків на утримання керівного апарату. Моніторинг наявної ресурсної бази, разом із вивченням реальних потреб $i$ можливостей територій громад необхідні для подальшого формування інвестииійної стратегії ОТГ. Кожний з регіонів України повинен мати інвестиційні паспорти ОТГ, які мають вміщати інформацію про
} 
економічний потенціал ОТГ, а ретельний аудит ресурсних баз ОТГ повинен стати основою для розробки стратегій економічного розвитку громад.

Ключові слова: громада, деиентралізація, індекс якості життя кожного представника територіальної громади, місиевого самоврядування, об 'єднаних територіальних громад, органів влади, розвитку економічного потенціалу, та ін.

The article outlines the range of decentralization tasks to increase the level of financial capacity of the community. The need for participation of territorial communities in the reforming of the domestic system of local government is noted. The main reasons for the problems of development of the economic potential of the united territorial communities of Ukraine are identified: 1) corrupt centralized vertical of state power and its irrational use of financial and natural resources; 2) the lack of an effective and practical mechanism of local government as a democratic mechanism of local government; 2) increasing level of citizens' distrust of state power; 3) financial and economic insolvency of the vast majority of communities; 4) insufficient level of competence of the vast majority of local authorities and public assets; 5) misunderstandings between local state institutions, lack of their responsibility to the community, etc. Organizational and economic approaches to stimulate entrepreneurial activity of community residents and intensify the business environment are proposed. Attention is paid to the study of the professional composition of the population, identification of sources and distribution of income, resources available in UTC. The list of priority issues for candidates to executive bodies and UTC Councils is given: 1) professional qualities and ability to be face to face with the community, which means bringing the system of local government in line with the Constitution of Ukraine and readiness to solve community problems; 2) the ability to organize communication: the community - the authorities, the creation of the Center for Public Communications; 3) establishing civilized relations with investors and private business: the community - the developers - the industrialists - the farmers (to build large industrial, residential, tourist, entertainment, infrastructure facilities - only with the permission of the community); 4) bringing the structure of local government to the best option, primarily the optimization of utilities; 5) to promote the development of the spheres of health care, education, children's and youth creativity and sports, culture, transport; 6) creation of an economic policy in the field of housing and communal services, protection of the interests of BSP; 7) creation and implementation of an economic and social development plan for UTC, which meets the interests of the local community. Two crucial indicators need to be used as the basis for UTC's economic and human potential. The first is the quality of life index of each member of the local community (health and longevity, access to education and a decent standard of living). This index will help keep people from migrating to other regions or abroad and, conversely, attract additional human resources. Regional competitiveness is the second most important index that determines the ability of regions to create an attractive environment for business and investment development. For this purpose, a national rating is formed taking into account the indicator of own revenues per capita, the level of budget subsidies, which should not exceed $30 \%$ of local revenues and capital expenditures per capita without subventions from the state budget and the share of expenditures for management. Monitoring of the available resource base, together with the study of the real needs and opportunities of community areas are necessary for the further formation of the investment strategy of UTC. Each of the regions of Ukraine should have UTC investment passports, which should contain information about the economic potential of UTC, and a thorough audit of UTC resource bases should be the basis for developing strategies for economic development of communities.

Keywords: community, decentralization, quality of life index of each representative of the territorial community, local government, united territorial communities, authorities, development of economic potential, etc.

Актуальність теми. Динамічний розвиток економічно розвинених країн світу доводить те, що неможливо забезпечити розвиток їх територій на сталому рівні без децентралізації та ефективного місцевого самоврядування. Як свідчить міжнародний досвід, без укрупнення громад неможливо посилити здатність територіальних громад до самостійної діяльності.

Головним пріоритетом національних інтересів будь-якої країни $\epsilon$ раціональне використання всіх іiї ресурсів, в першу чергу людських та природних. Процвітання та добробут регіонів країни залежить переважно від того, наскільки успішно ці території зможуть самоорганізуватися та узгодити діяльність всіх іiі членів задля досягнення їх спільних цілей. Успішна реалізація цієї мети майже неможлива без реальної децентралізації для створення в громадах достатнього місцевого бюджету, який буде спроможним вирішувати пріоритетні та нагальні проблеми районів, міст, селищ без вказівок з центральних державних установ. Тому основними реальними та потенційними загрозами економічної незалежності та екологічної безпеки України i стабільності в суспільстві - $\epsilon$ корумпована централізована вертикаль державної влади та нераціональне використання нею фінансових і природних ресурсів. Органи місцевого самоврядування кожної територіальної громади мають бути ефективними господарями та професійно діяти в умовах специфіки свого природного, екологічного, туристичного та промислового потенціалу і нести повну відповідальність за використання ресурсів на місцевому рівні, а центральна державна влада повинна здійснювати необхідний моніторинг і контроль законності та відсутності зловживань місцевої влади.

Для запобігання загрозам економічної незалежності та екологічної безпеки України та створення безпечних екологічних умов життєдіяльності населення перед органами 
державної влади та органами місцевого самоврядування ставиться завдання формування збалансованої системи природокористування та підвищення ефективності використання всіх необхідних ресурсів.

Аналіз останніх досліджень. Проблемам розвитку об'єднаних територіальних громад регіонів України присвячено ряд наукових досліджень вітчизняних та зарубіжних вчених, зокрема таких як: С. Бородін, Н. Гончарук, І. Грицяк, Г. Колесникова, А. Колодій, Ю. Наврузов, П. Надолішний, Дж. Неліс, Н. Нижник, В. Огаренко, Г. Райт, Р. Рибіков, Д. Рондинеллі, С. Серьогін, А. Трачук, Ю. Шаров та багатьох інших. Водночас розвиток економічного потенціалу об'єднаних територіальних громад регіонів України залишається сьогодні поза увагою органів влади, що демонструє значне відставання темпів його зростання від аналогічних форматів розвинутих країн та відповідно ставить нові завдання щодо модернізації вітчизняної економіки 3 орієнтацією на розвиток місцевого самоврядування і формування активного та відповідального громадянського суспільства. Зокрема, реформа бюджетної децентралізації, що має бути фундаментом для розвитку економіки нашої країни сьогодні ускладнена цілим рядом економічних, політичних, соціальних, психологічних факторів, починаючи від сталої і надпотужної корупції центральних органів влади та закінчуючи свідомістю сприйняття процесів децентралізації та об'єднання територіальних громад пересічними українцями. Все це потребує консолідації зусиль усіх рівнів влади, активних та небайдужих громадян та постійної підтримки міжнародних партнерів.

Постановка проблеми. Наша країна вже давно розпочала реформування місцевого самоврядування на основі децентралізації, натомість цей процес значно затягнувся та характеризується лише окремими випадками ефективності розвитку на деяких окремих територіальних одиницях. Обумовлено це, в першу чергу, економічно-фінансовою неспроможністю переважної більшості громад, фактичною відсутністю коштів у бюджетах розвитку та інвестицій в інфраструктури (переважно комунальної), а по-друге, недостатньою компетентністю як органів місцевої влади так і громадського активу, непорозумінням між місцевими державними установами та фактично відсутністю їх відповідальності перед громадою тощо.

Сьогодні є всі підстави стверджувати те, що низька якість державного управління в нашій країні суттєво позначається на розви- тку децентралізації та розвитку місцевого самоврядування самим негативним чином. Очевидним є і те, що більшість представників органів державної влади (держслужбовців) використовуючи службове положення, здебільше зайняті вирішенням своїх особистих інтересів і не виконують головну ціль державного управління - забезпечення якості життя громадянського суспільства. Відтак, перед вітчизняним державним управлінням залишається невирішеним ціле коло проблем місцевого самоврядування, які не можуть залишатися без відповідної реакції. Тому необхідно шукати більш глибинні шляхи вирішення цього питання на «адаптивній» основі в контексті формування активного громадянського суспільства, щоб сприяти максимальному наближенню якості державних послуг до населення, підвищенню можливостей і повноважень територіальних громад та їх представницьких органів для вирішення економічних питань місцевого значення власними силами, що створить потужний потенціал для ефективного розвитку економіки країни.

Мета - висвітлити головні причини, що перешкоджають розвитку економічного потенціалу об'єднаних територіальних громад регіонів України, запропонувати шляхи іiі вирішення.

В умовах економічно-політичної нестабільності Україна обрала зовнішньополітичний курс на інтеграцію до європейської спільноти, що має відбуватися через дієве реформування органів влади. Одним 3 головних завдань, що потребує ретельної уваги в умовах реального стану розвитку економіки, $\epsilon$ орієнтування територіальних громад на участь в реформуванні вітчизняної системи місцевого самоврядування.

Для забезпечення успіху цієї реформи велике значення має надання можливостей громадам розвиватись, всебічно допомагати та сприяти забезпеченню цього процесу. Реформа децентралізації здійснюється 3 передачею повноважень від центральної влади органам місцевого самоврядування (місцевим радам та їх головам), яких мешканці територіальних громад обирають собі, та надання фінансових ресурсів для здійснення ними соціально-економічної діяльності 3 відповідальністю за їх виконання. Вихідним пунктом цієї реформи є усвідомлення, що органам місцевого самоврядування на місцях краще орієнтуватися в проблемах їх території [3, с. 215].

Головною метою децентралізації $є$ наближення місцевої влади до реальних потреб жителів зі зворотнім зв'язком для підвищення якості життя мешканців даної територіальної 
одиниці, а саме для забезпечення доступності та якості медичних, освітніх, адміністративних, культурних, комунальних та соціальних послуг. Підвищення ефективності, економне та раціональне використання наявних ресурсів, зі збереженням своєї природної спадщини та екології довкілля в належному стані для наступного покоління, потребує надійної теоретичної бази і практичних навичок у керівників місцевого самоврядування, які мають опікуватися питаннями розвитку об'єднаних територіальних громад.

До головних завдань органів місцевого самоврядування належить: задоволення потреб місцевого населення; сприяння підвищенню рівня відповідальності органів влади та прозорості їх діяльності шляхом надання можливості громадянам контролю за діяльністю органів влади; децентралізація повноважень органів влади, що є сутністю адміністративної реформи шляхом передачі та раціонального розподілу на місцях значущих повноважень органам самоорганізації населення $(\mathrm{OCH})$.

Конституцією і Законом України «Про місцеве самоврядування в Україні» поняття «територіальна громада» визначено як сукупність мешканців (громадян), які об'єднані постійним проживанням у межах певної територіальної одиниці (села, селища, міста), що $\epsilon$ самостійними адміністративно-територіальними одиницями і $є$ добровільними об'єднаннями мешканців (наприклад декількох сіл, що мають єдиний адміністративний центр) [1].

3 метою розвитку економічного потенціалу об'єднаних територіальних громад вивчаються взаємозв'язки різних секторів економіки, домогосподарств та підприємств. Увага приділяється дослідженню професійного складу населення, визначенню джерел та розподілу доходів, ресурсів, наявних у ОТГ.

Для реформування застарілої моделі самоврядування впроваджено новий формат місцевого управління: Об'єднані територіальні громади (ОТГ) - об'єднання жителів розрізнених населених пунктів (сіл, селищ або міст) в одну укрупнену територіально-адміністративну одиницю. Об'єднана територіальна громада (ОТГ) формується на певній території та $є$ суб'єктом управління іiї соціально-економічним розвитком. Відповідно членами ОТГ $\epsilon$ фізичні особи, які або проживають на цій території, або працюють, або володіють певним нерухомим майном. Місцева спільнота $\epsilon$ власником комунального майна, розміщеного на іiі території, а іiї члени, відповідно до законодавства, $є$ платниками податкових платежів до місцевого бюджету. Громада функціонує для забезпечення іiі членів якісними громадськими послугами, може виступати учасником виробничих процесів та $є$ колективним споживачем, а також функціонує для забезпечення власної спроможності [2, с. 133].

Об'єднання має відбуватися на добровільних засадах, а для організації ефективності процесу державна влада (в особі районних та обласних держадміністрацій, за участі громадськості, ОСН, експертів) розробила орієнтовні межі об'єднань і перспективні плани формування ОТГ України. Внаслідок таких нових об'єднань створюються нові адміністративні центри і нові, об'єднанні органи місцевого самоврядування від усіх населених пунктів, які увійшли до ОТГ.

Після створення ОТГ воно стає правонаступником всього майна, прав та обов'язків громад населених пунктів та сільських, селищних, міських рад, що об'єдналися. При цьому села 3 кількістю від 50 мешканців обирають сільського старосту, який в свою чергу, входити до виконкому ОТГ. Таким чином сільський староста $є$ представником жителів села/селища, яке входить в ОТГ, і вважається ланкою місцевої влади, та несе відповідальність за свій округ.

Для здійснення місцевого управління мешканцями ОТГ обирається Рада об'єднаної територіальної громади, яка повністю підпорядковується громаді. Рада ОТГ формує виконавчий комітет, в завдання якого входить контроль за фінансовими ресурсами громади та має повноваження встановлювати i змінювати місцеві податки. Рішенням ради надаються в оренду земельні ділянки та комунальні приміщення громади та визначаються відсоток їх орендної ставки.

Розподіл на нові адміністративні райони, як важливий етап реформи децентралізації по своїй суті і $є$ реалізацією реформи адміністративного устрою, яка завершиться 25 жовтня 2020 р., після того, як пройдуть вибори органів місцевого самоврядування. Даний виборчій процес буде здійснений вже в рамках новосформованих районів (ОТГ).

Стратегічною складовою ефективного економічного розвитку кожної окремої ОТГ має бути фахове визначення специфіки її економічного потенціалу (спадщини природних ресурсів та різних господарських галузей промислової, наукової, аграрної, туристичної тощо). Але ключовим фактором ефективності реформи безумовно $є$ рівень якості життя в даному регіоні та людський потенціал 3 їх професійною ментальністю, рівнем кваліфікації, загальним ставленням до реформ, 3 їх 
громадянською зрілістю і відповідно наявності бажання участі в управлінні ОТГ [4].

Відсутність ефективного та практичного механізму місцевого самоврядування, як демократичного механізму місцевого управління, протягом довгого часу поглиблювало загальну критичну недовіру суспільства до центральної державної та виконавчої влади. Дефіцит довіри до державної влади набув критичної межи, тому застосування в місцевому управлінні ідеології та підходів бізнес-управління має сприяти налагодженню рівноправних стосунків між владою та громадянами на основі надання, вироблених владою в умовах політичної конкуренції, якісних адміністративних послуг. Виконавче керівництво ОТГ повинно позиціонувати себе з менеджментом, який безпосередньо зацікавлений в залученні інвестицій до інфраструктури ОТГ, що підвищить об'єм сплати податків, наповнення місцевих бюджетів і надасть можливість для здійснення соціальних проектів.

Здійснення ефективного місцевого самоврядування безпосередньо в ОТГ і формування в них особливого муніципального середовища - впевнений шлях до розвинутого громадянського суспільства, бо саме в муніципальному середовищі серед громадян народжується солідарність і колективна свідомість.

В сучасному корумпованому і не правовому українському суспільстві вкрай необхідна нова модель місцевого самоврядування з пріоритетом громади, побудованої на принципах субсидіарності та децентралізації. Прогресивний, економічний та соціальний розвиток українського суспільства гальмувався відсутністю реальних територіальних громад на місцях, хоча цього вимагає Конституція України.

Перелік пріоритетних питань кандидатам до виконавчих органів та Рад ОТГ, на наш погляд визначається в такому порядку:

- професійні якості і здатність бути віч-навіч з громадою, що означає приведення системи місцевого самоврядування у відповідність з Конституцією України та готовність вирішувати проблеми громади;

- вміння організувати комунікацію: громада - органи влади, створення Центру громадських комунікацій;

- налагодження цивілізованих відносин 3 інвесторами та приватним бізнесом: громада - забудовники - промисловці - аграрії (будувати великі промислові, житлові, туристичні, розважальні, інфраструктурні об'єкти тільки 3 дозволу громади);

- приведення структури місцевого управління до оптимального варіанту, в першу чергу оптимізація комунальних підприємств;
- особливу увагу надавати розвитку сферам охорони здоров'я, освіти, дитячої та молодіжної творчості і спорту, культури, транспорту;

- створення економної політики в сфері ЖКГ, захист інтересів ОСН;

- створення та здійснення економічного та соціального плану розвитку ОТГ, який відповідає інтересам місцевої громади.

За основу економічного та людського потенціалу ОТГ необхідно застосовувати два надважливих показника, перший з яких - індекс якості життя кожного представника територіальної громади, який є головним і базується на таких основних складових, як здоров'я та довголіття, доступність освіти і гідний рівень життя. Саме цей індекс допоможе втримати людей від міграції в інші регіони або за кордон і навпаки залучити додатковий людський ресурс. Конкурентоспроможність регіонів це другий надважливий індекс, який визначає здатність регіонів створити привабливе середовище для розвитку бізнесу та інвестицій.

3 цією метою формується загальнонаціональний рейтинг з урахуванням таких показників, як показник про власні доходи на одного мешканця, рівня дотаційності бюджету, що не повинен перевищувати $30 \%$ від суми місцевих доходів та капітальних видатків на одного мешканця без субвенцій з держбюджету, та питомої ваги видатків на утримання керівного апарату.

Найважливіше на сьогодні питання - це питання підвищення рівня фінансової спроможності громади, яке вирішується завдяки забезпеченню стратегічним управлінням розвитку ОТГ та шляхом розвитку економіки в пріоритетних галузях, здебільше підтримки діяльності малому та середньому бізнесу на своїх територіях, сприяння залученню інвестицій. Кожній з ОТГ необхідно визначити пріоритетні галузі на своїх територіях, виходячи з природних та людських ресурсів, промислової, аграрної, наукової, туристичної спадщини тощо. Традиційно на сільських територіях надають перевагу фермерству для вирощування певних аграрних культур, які $\epsilon$ характерними для їх територій та розвитку галузей АПК [5, с. 87]. Моніторинг наявної ресурсної бази, разом із вивченням реальних потреб і можливостей територій громад необхідні для подальшого формування інвестиційної стратегії ОТГ. Кожний з регіонів України повинен мати інвестиційні паспорти ОТГ, які мають вміщати інформацію про економічний потенціал ОТГ, а ретельний аудит ресурсних баз ОТГ повинен стати основою для розробки стратегій економічного розвитку громад. 
Управління ресурсами, що належать до комунальній власності і створюють матеріально-фінансову основу місцевого самоврядування, здійснюється виконавчими органами ОТГ у межах наданих їм законодавством повноважень. Пропозиції щодо розміщення на відповідній території підприємств, спеціалізації та розвитку промислових організацій незалежно від форми їх власності, ефективне використання природних ресурсів-основоположна функція органів місцевого самоврядування. Цей напрямок місцевого управління повинен бути забезпечений шляхом створення відповідних стратегічних планів економічного розвитку даної території із залученням досвідчених фахівців в галузях природокористування, екології та економіки, які повинні опікуватися цими питаннями. Плата за використання природних ресурсів $є$ важливим джерелом підвищення доходів місцевих бюджетів, але вона повинна бути адекватно-прорахованою, з урахуванням середньостатистичної вартості аналогічних ресурсів в інших регіонах країни та світових тенденцій. Тільки на основі ретельного аналізу економічного стану місцевої промисловості та бізнесу повинно прийматися рішення щодо залучення інвесторів та виробників з інших регіонів, або іноземних компаній. В пріоритеті для надання дозволу видобування або використання природних ресурсів та розміщення промислових, аграрних та інших підприємств завжди повинні бути представники місцевого і вітчизняного бізнесу.

Згідно пріоритетних напрямів діяльності означених в Свропейській Хартії міст та Хартією українських міст, органи місцевого самоврядування зобов'язані створювати на своїх територіях природно-екологічні консервації (заповідники) для розширення використання громадою відкритих просторів і рослинних ресурсів, які вважаються суттєвими чинниками що впливають на самовдосконалення i розвиток особистості та надають можливості для екологічного виховання і спілкування 3 природою мешканців і в першу чергу дітей, які проживають в міському середовищі.

Перелік податкових та неподаткових надходжень місцевих бюджетів об’єднаних тери- торіальних громад детально викладено у статтях 64, 69-1, 71 Бюджетного кодексу України $[2$, с. 76]. Перелік повноважень і завдань для керівництва та органів місцевого самоврядування можна продовжувати, але проблема полягає не в їх кількості, а в тому, що для їх вирішення необхідно застосувати головний фактор економічного розвитку - моніторинг та підвищення якості життя кожного представника громади.

Негативний вплив на підприємницьке середовище в громаді здійснює домінування короткотермінових інтересів, відсутність стратегічного плану розвитку конкретної територіальної громади, та не визначення основних чинників конкурентоспроможності громади для залучення на їх територію інвестиційних ресурсів та підприємницьких структур. Шляхом ефективного використання повноважень органів місцевого самоврядування у сфері планування та розпорядження земельними ресурсами, встановлення місцевих податків та зборів, розпорядження комунальною власністю необхідно застосування в територіальних громадах нових організаційно-економічних підходів для стимулювання підприємницької активності мешканців громади і активізації підприємницького середовища.

Висновки. Таким чином, доведено, що ефективність розвитку економічного потенціалу новостворених, в рамках адміністративної реформи, об'єднаних територіальних громад України більшою мірою залежить від урахування керівництвом місцевого самоврядування основоположних факторів - індексу якості життя кожного представника територіальної громади, який є головним і базується на таких основних складових, як здоров'я та довголіття, доступність освіти і гідний рівень життя, та визначення пріоритетних галузей господарства на своїх територіях, виходячи з природних та людських ресурсів, промислової, аграрної, наукової, туристичної спадщини, що визначає другий надважливий індекс - конкурентоспроможність ОТГ, який визначає здатність регіону створити привабливе середовище для розвитку бізнесу та інвестицій.

\section{Список використаних джерел:}

1. Про добровільне об’єднання територіальних громад [Текст] : Закон України від 05.02.2015 p. № 157-УШ. URL: http://www.rada.gov.ua.

2. Управління стратегічним розвитком об'єднаних територіальних громад: інноваційні підходи та інструменти : монографія / С.М. Серьогін, Ю.П. Шаров, С.І. Бородін, Н.Т. Гончарук [та ін.] ; за заг. та наук. ред. С.М. Серьогіна, Ю.П. Шарова, Дніпро : ДРІДУ НАДУ, 2016. 276 с.

3. Системна модернізація державного управління в Україні: гуманістичний контекст: кол. монографія / Братусь Г.А., Головач Н.В., Дмитренко Г.А., Дорошенко Л.С., Згалат-Лозинська Л.О. та ін. / за заг. ред. Г.А. Дмитренка. Київ : ДКС-Центр, 2020. 512 с. 
4. Патицька X. Фінансово-економічний потенціал територіальних громад: механізми функціонування та активізації: монографія. ДУ «Інститут регіональних досліджень імені М.I. Долішнього НАН України». Львів, 2019. 209 с.

5. Управління розвитком об’єднаних територіальних громад на засадах громадської участі : навч. посіб. / О.В. Берданова, В.М. Вакуленко, Н.М. Гринчук, В.С. Колтун, В.С. Куйбіда, А.Ф. Ткачук. Київ, 2017. $129 \mathrm{c}$.

\section{References:}

1. Pro dobrovilne obednannya teritorialnih gromad : Zakon Ukrayini vId 05.02.2015 r. № 157-VIII [On a voluntary association of communities : Law of Ukraine of 02.05.2015 p. № 157-VIII]. Available at: http://zakon4.rada.gov.ua/laws/show/157-19. (in Ukrainian)

2. Serohin S.M. Sharov Yu.P., Borodin Ye.I., Honcharuk N.T. et al. (2016) Upravlinnia stratehichnym rozvytkom obiednanykh terytorialnykh hromad: innovatsiini pidkhody ta instrument [Management of strategic development of joint territorial communities: innovative approaches and tools]. Dnipropetrovsk. (in Ukrainian)

3. Bratus G.A., Golovach N.V., Dmytrenko G.A., Doroshenko L.S., Zgalat-Lozynska L.O. ta in. (2020) Systemna modernizaciya derzhavnogo upravlinnya v Ukrayini: gumanistychnyj kontekst: kol. monografiya [Systematic modernization of public administration in Ukraine: humanistic context]. Za zag. red. G.A. Dmytrenka. Kyiv: DKS-Centr. (in Ukrainian)

4.PatyczkaX.(2019)Finansovo-ekonomichnyjpotencialterytorialnyx gromad: mexanizmy funkcionuvannya ta aktyvizaciyi: monografiya [Financial and economic potential of territorial communities: mechanisms of functioning and activation: monograph]. DU «Instytut regionalnyx doslidzhen imeni M.I. Dolishnogo NAN Ukrayiny». Lviv. (in Ukrainian)

5. Berdanova O.V., Vakulenko V.M., Grynchuk N.M., Koltun V.S., Kujbida V.S., Tkachuk A.F. (2017) Upravlinnya rozvytkom obyednanyx terytorialnyx gromad na zasadax gromadskoyi uchasti: navch. posib. [Managing the development of united territorial communities on the basis of public participation: a guide]. Kyiv. (in Ukrainian) 